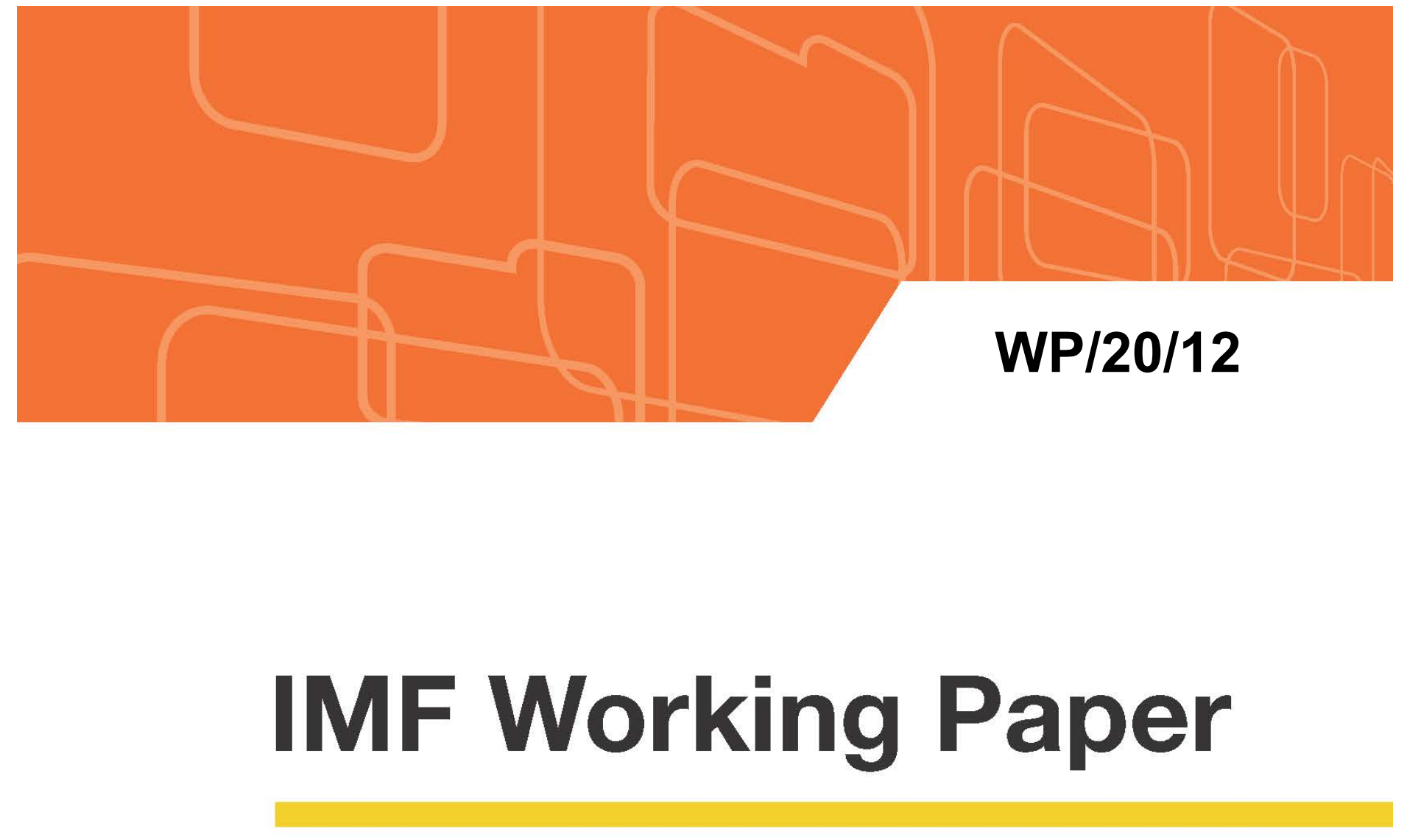

\title{
Exploring the Output Effect of Fiscal Policy Shocks in Low Income Countries
}

by Jiro Honda, Hiroaki Miyamoto, and Mina Taniguchi

I N T E R N A T I O N A L M O N E T A R Y F U N D 


\title{
IMF Working Paper
}

Fiscal Affairs Department

\section{Exploring the Output Effect of Fiscal Policy Shocks in Low Income Countries ${ }^{1}$ \\ Prepared by Jiro Honda, Hiroaki Miyamoto, and Mina Taniguchi}

Authorized for distribution by Nikolay Gueorguiev

January 2020

IMF Working Papers describe research in progress by the author(s) and are published to elicit comments and to encourage debate. The views expressed in IMF Working Papers are those of the author(s) and do not necessarily represent the views of the IMF, its Executive Board, or IMF management.

\begin{abstract}
What do we know about the output effects of fiscal policy in low income countries (LICs)? There are very few empirical studies on the subject. This paper fills this gap by estimating the output effects of government spending shocks in LICs. Our analysis-based on the local projection method-finds that the output effects in LICs are markedly lower than those in AEs and marginally smaller than those in EMs. We also find that in LICs, the output effects are larger (i) during recessions; (ii) under a fixed exchange rate regime; and/or (iii) with higher quality of institutions. Our analysis could not confirm any statistically significant output effect under floating exchange rate regimes. For the estimation of the output effects of fiscal spending shocks, it is thus important to consider the state of the economy and the country's structural characteristics. Our results imply that the output costs of fiscal adjustment in LICs may not be as large as previously thought, especially if adopted outside of a recession, based on cutting public consumption, and accompanied by reform to enhance institutions.
\end{abstract}

JEL Classification Numbers: E62, H30, H50, O23

Keywords: Fiscal Policy; Fiscal Multipliers; Low Income Countries

Authors' E-Mail Addresses: JHonda@imf.org; HMiyamoto@imf.org;

mina.taniguchi0129@gmail.com

\footnotetext{
${ }^{1}$ We are grateful for helpful comments and suggestions from Vitor Gaspar, Nikolay Gueorguiev, Celine Allard, Sandesh Dhungana, Giovanni Melina, Kenji Moriyama, Chris Papageorgiou, Marcos Poplawski Ribeiro, Hoda Selim, and participants of IMF's Fiscal Affairs Department seminar. The authors are grateful to Paulomi Mehta for her research assistance, and Sofia Cerna Rubinstein and Julie Vaselopulos for editorial assistance.
} 
ABSTRACT

II. LITERATURE REVIEW _____________________________________________ 6

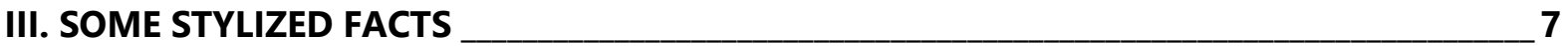

IV. EMPIRICAL METHODOLOGY AND DATA _______________________ 9

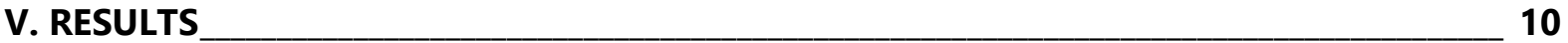

VI. CONCLUSION AND POLICY IMPLICATIONS ________________ 20

REFERENCES ________________________________________________ 22

BOX

1. Initial Capital Stock and Public Investment Shocks in LICS 19

\section{FIGURES}

1. Key Determinants of the Size of Fiscal Multiplier by Income Group 8

2. Effects of Government Spending Shocks on Output 11

3. Output Effects of Different Fiscal Policy Shocks in LICs 12

4. Output Effects of Fiscal Policy Shocks Over Business Cycles in LICs 14

5. Output Effects of Government Spending Shocks Under Different FX regimes in LICs 16

6. Effects of Government Spending Shocks: The Role of the Institution Quality in LICs 16

7. Relative Importance of Determinants

\section{ANNEXES}

I. Impacts of Fiscal Spending Shocks on Private Consumption and Investment 25

II. Impacts of Fiscal Spending Shocks on Private Consumption and Investment in LICS

During Booms 26

III. Output Effects of Fiscal Spending Shocks Under Floating Exchange Rate Regimes 27

IV. Possible Determinants of the Size of Fiscal Multiplier 


\section{INTRODUCTION}

1. Policymakers and economic researchers in low income countries (LICs) need a better understanding of the output effects of fiscal policy. Countries shift their fiscal positions with an aim to achieve fiscal sustainability or respond to aggregate demand shocks. In either case, it is essential to examine the accurate relationship between the changes in fiscal positions and growth. This is particularly important for LICs as an increasing number of LICswith serious debt challenges_-face the need for fiscal adjustment (IMF, 2018). In light of significant social needs and wide-spread poverty in those countries, however, such adjustment would need to be undertaken without excessively undermining growth and employment. Thus, to explore the scope for fiscal adjustment, an accurate forecast of the output effects of fiscal policy is a prerequisite.

\section{A priori, it is unclear whether output effects of fiscal shocks would be higher or} lower in LICs than in other country groups. As summarized in IMF (2014), for LICs, monetary response is generally less effective, and automatic stabilizers are lower, both of which may contribute to higher output effects of fiscal policy. There are, however, some other factors which may dampen the effects. Precautionary saving, for instance, may be larger in a more uncertain environment, while LIC economies are generally smaller (with a smaller industrial base) and more open than EMs and AEs. Also, LICs often face chronically high unemployment, possibly implying that their economies are producing below full-employment capacity. This may in theory magnify the effect of fiscal policy in LICs.

3. There is, however, little empirical evidence on the output effects of fiscal policy in LICs, despite a large body of literature examining AEs and emerging market economies (EMs). This is mainly owing to data limitations and difficulties in identifying fiscal policy shocks (i.e., exogenous changes in government spending that are not correlated with contemporaneous macroeconomic shocks). However, the few available empirical studies suggest that output effects of fiscal policy in developing countries are lower than AEs. ${ }^{2}$

\section{This paper examines the output effects of fiscal spending shocks in LICs. For this}

purpose, we identify the fiscal policy shock as the forecast error of government spending and use the local projection method to estimate the impulse response of output to fiscal policy shocks. This approach overcomes the data limitation issue that prevents estimating fiscal multipliers in

\footnotetext{
${ }^{2}$ IMF (2017) finds that fiscal multipliers in sub-Saharan Africa tend to be smaller than those typically identified in AEs or EMs.
} 
LICs. We also explore the determinants of the size of the fiscal multipliers. ${ }^{3}$ Specifically, we examine the following empirical questions:

- Are the output effects of fiscal spending shocks in LICs different from those in AEs or EMs?

- What factors would affect the size of the output effects in LICs?

\section{We answer these questions with empirical evidence.}

- First, the output effects of fiscal spending shocks in LICs are notably smaller than those in AEs and marginally smaller than in EMs. We find that a positive government spending shock of one percentage point of GDP increases output by 0.1 percent in the same year and its impact disappears three years after the shock. On average, the fiscal multipliers in LICs are less than half of those in AEs.

- Second, in LICs, the size of fiscal multipliers is larger than otherwise in the following instances: (i) during recessions; (ii) under fixed exchange rate regime; and (iii) with higher quality of institutions. Among these factors, the cyclical state of the economy is the most significant determinant of the output effects. However, under floating exchange rate regimes, positive output effects are not found even during recessions.

6. Our results suggest several important policy implications. First, output effects in LICS vary with the state of the economy, the country's exchange rate regime, and institutional capacity. Second, given our result of the low output effect of fiscal spending in LICs, the costs of fiscal adjustment may be lower than previously thought. Third, our results confirm that undertaking countercyclical fiscal policy is still helpful under a fixed exchange rate, but less so under floating exchange rate regimes. Lastly, our results also suggest that LICs should strengthen institutional quality to enhance the benefits of fiscal stimulus.

7. The remaining sections of the paper are organized as follows. Section II briefly reviews the existing literature. Section III describes the data and presents the empirical methodology used to estimate fiscal multipliers. Section IV presents the main findings. Finally, Section $V$ provides the conclusion and draws policy implications.

\footnotetext{
${ }^{3}$ In this paper, fiscal multipliers and output effects of government spending shocks are used interchangeably. In general, fiscal multipliers are defined as the ratio of a change in output to a discretionary change in government spending. For this purpose, this paper-following the methodologies widely used in the literature-identifies government spending shocks as forecast errors of government spending and estimate their impacts on output. Thus, in an attempt to describe the exercise more accurately, this paper predominantly uses the term "the output effects of government spending shocks".
} 


\section{LITERATURE REVIEW}

8. In recent years, interest in the size of the fiscal multipliers has resurged. Following the economic crisis of 2008-09, large fiscal stimuli have been implemented around the globe. The discussion on its effectiveness initiated a debate on the size of fiscal multipliers (see Ramey (2011) for a detailed literature review).

\section{There are several transmission channels through which fiscal policy would affect} growth. A standard new Keynesian model predicts that an expenditure expansion stimulates labor demand, and thus increases wages and consumption. On the other hand, the standard neoclassical models predict that due to the negative wealth effect, private consumption and the real wage fall following a positive government spending shock. The existing empirical evidence for AEs appears consistent with either view (Ramey and Shapiro, 1998; Blanchard and Perotti, 2002). However, such transmission channels may not be similarly effective in LICs. For example, the wealth effect requires the developed financial market, but in LICs, financial markets are often not sufficiently developed.

\section{The empirical studies on AEs identify different size of the output effects depending}

on the state of an economy and their structural characteristics. As summarized in IMF (2014), the literature finds that fiscal multipliers are generally larger in downturns than in expansions (Auerbach and Gorodnichenko, 2012; IMF, 2014). Previous empirical studies also identify several more important determinants of the size of multipliers: (i) exchange rate regimes (Born et al., 2013; Ilzetzki et al., 2013); (ii) trade openness (IMF, 2008; Barrel et al., 2012; Ilzetzki et al., 2013); ${ }^{4}$

(iii) the public debt level (Kirchner et al., 2010); (iv) labor market rigidity (Cole and Ohanian, 2004);

(v) size of automatic stabilizer (Dolls et al., 2012); and/or (vi) institutional quality (IMF, 2014).

11. There are, however, very few empirical studies on fiscal multipliers in LICs. ${ }^{5}$ The scare empirical studies suggest that fiscal multipliers in developing countries are lower than developed economies. Ilzetzki et al., (2013) find negative but insignificant government consumption multipliers for developing countries. Kraay $(2012,2014)$ estimates the fiscal multipliers using the cross-country panel data including LICs. Kraay (2014) also estimates a fiscal multiplier of about 0.4 in developing countries and finds that they are larger in recessions,

\footnotetext{
${ }^{4}$ According to Keynesian models, trade linkages reduce the effectiveness of fiscal policy. Ilzetzki et al., (2013) support this conventional view. They find that on average fiscal multipliers are smaller in economics with more open economies. In contrast, Cacciatore and Traum (2019) show that fiscal multipliers can be larger in economies more open to trade in a simple two-country, two-good model. Koh (2017) finds that fiscal multipliers are not necessarily smaller in countries that are relatively open to trade by using panel data analysis of 120 countries over the period 2006-2014.

${ }^{5}$ Shen et al., (2018) provides a conceptual framework to analyze the fiscal policy effects in LICs by developing a New Keynesian small open economy model.
} 
in closed economies, and in countries with flexible exchange rate regimes. ${ }^{6}$ Furceri and $\mathrm{Li} \mathrm{(2017)}$ examine the output effects of public investment shocks in 79 emerging market and low-income countries. They find a short-term fiscal multiplier of 0.2 for developing countries. Similarly, estimated fiscal multipliers in sub-Saharan Africa tend to be smaller than those typically identified in EMs and AEs (IMF, 2019). IMF (2014) suggests the application of the so-called "bucket approach" for LICs, based on the estimates on AEs.

\section{SOMe StyLized Facts}

12. By looking at macroeconomic factors relevant for the size of fiscal multipliers, there is apparently high heterogeneity across income groups (Figure 1). Specifically, we examine six elements of the macroeconomic environment relevant for the size of fiscal multipliers as identified in the existing literature. Those elements are: (i) the exchange rate regime, (ii) trade openness; (iii) the public debt level; (iv) labor market rigidity; (v) the size of automatic stabilizers; and (vi) institutional quality.

13. For each element there is a large variance within each income group on top of large differences across income groups. Data shows that compared with AEs and EMs, LICs tend to have slightly lower trade openness, less flexible exchange rate regimes, smaller automatic stabilizers, and lower quality of intuitions. As for the public debt, although the median debt-toGDP ratio in LICs is smaller than that of AEs, the difference is not large by taking into account the large variance in AEs. Interestingly, there is no significant difference in labor market rigidity between LICs and others. However, it is well known that developing economies have larger informal markets than developed economies.

\section{It is, however, not clear if these analytical results suggest higher or lower output}

effects for LICs. This is because some factors tend to increase fiscal multipliers, while others tend to reduce them. For example, while countries with a lower propensity to import tend to have higher fiscal multipliers, fiscal multipliers are expected to be smaller when institution quality is low.

\footnotetext{
${ }^{6}$ Kraay (2014)'s finding on countries with flexible exchange rate regimes differs from other analyses (e.g., Born et al., (2013) and Ilzetzki et al., (2013)). They find that fiscal multipliers are higher under fixed exchange rate regimes (consistent with the prediction of the Mundell-Fleming model with capital mobility).
} 


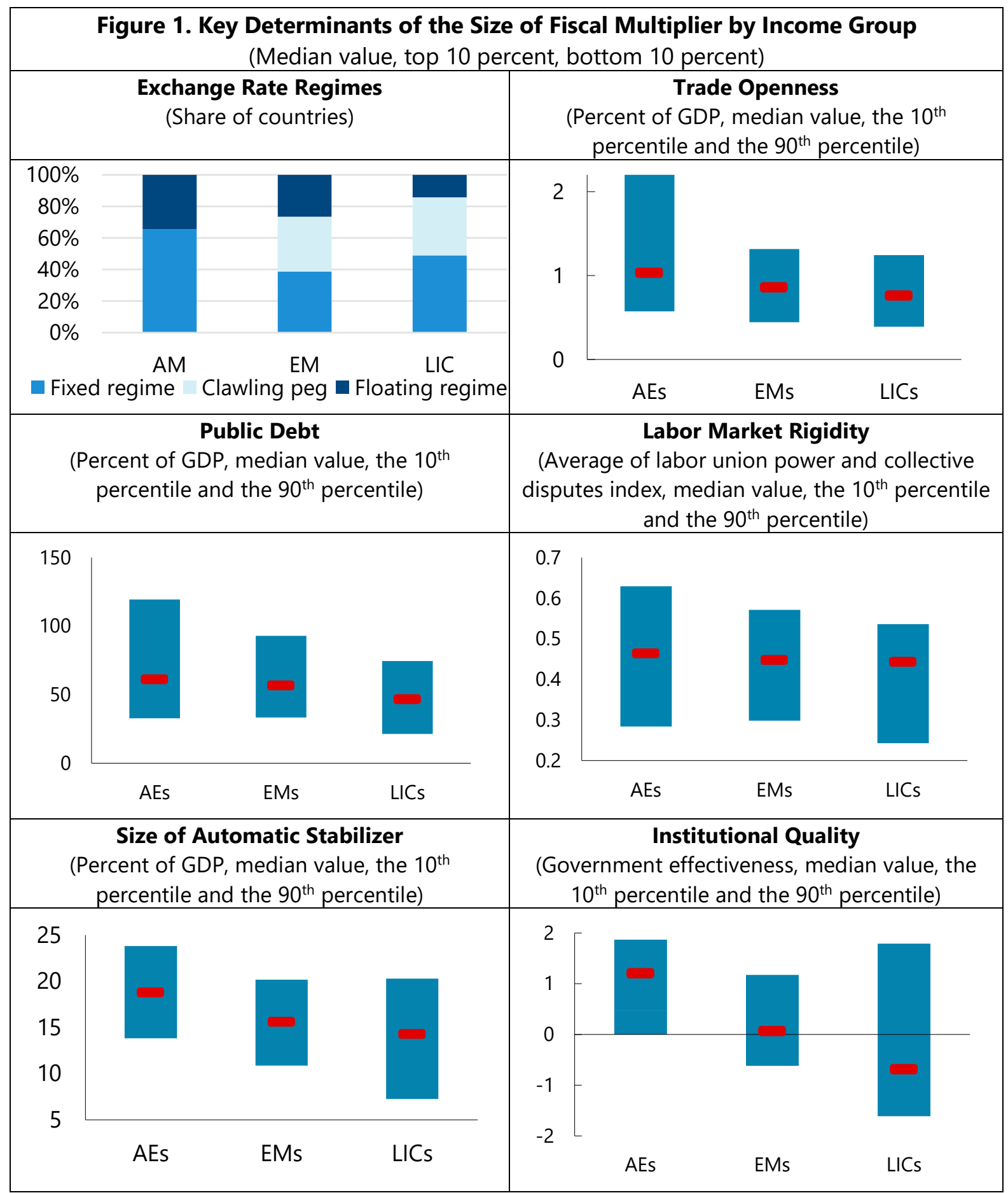

Note: The exchange rate regime is based on the de facto exchange rate arrangement classification of Ilzetzki et al., (2017). The trade openness is measured by the trade-to-GDP ratio. To measure the degree of labor market rigidity, we use an index averaging labor union power and collective disputes from Botero et al., (2004). Following IMF (2014), automatic stabilizers are measured by a ratio of public spending to nominal GDP. The quality of institution is measured by the World Bank's government effectiveness indicators.

Sources: Botero et al., (2004), Ilzetzki et al., (2017). IMF, and WB. 


\section{EMpirical Methodology and Data}

15. Following the approaches widely used in the literature, our empirical methodology is based on the local projection method using forecast errors. To examine the output effect of fiscal policy, we adopt the approach of Auerbach and Gorodnichenko $(2012,2013)$ and identify unexpected changes in fiscal policy (i.e., shocks) using forecast errors-the difference between actual government spending and its forecast. This identification method overcomes two challenges often associated with the estimation of fiscal multipliers, namely the "fiscal foresight" problem (Leeper, Richter, and Walker, 2012; Leeper, Walker, and Yang, 2013) and the potential feedback from the state of the economy to fiscal policy. ${ }^{7}$ We then use the identified fiscal spending shocks to estimate the output effect of fiscal policy by employing the local projection method of Jordà (2005). ${ }^{8}$ The local projection method is viewed as a flexible alternative to the vector autoregression (VAR) model, which is typically used to estimate fiscal multipliers. As the local projection method does not require high frequency data, it is suitable to analyze LICs.

\section{The fiscal spending shocks are identified by using the vintage data of the IMF's} World Economic Outlook (WEO). ${ }^{9}$ Following IMF (2014) and Furceri and Li (2017), forecasts of government spending are taken from October publications of the IMF's WEO. Then, the fiscal spending shocks are identified as the forecast errors of government spending. Thus,

$$
F E_{i, t}=g_{i, t}^{\text {Actual }}-g_{i, t}^{\text {Forecast }}
$$

where $g_{i, t}=G_{i, t} / Y_{i, t}$ is government spending as a share of GDP. The actual government spending comes from the October WEO of the following year. ${ }^{10}$

\footnotetext{
${ }^{7}$ Economic agents receive signals about future changes in fiscal spending policy before they actually take place, which may affect their decisions. This is known as the fiscal foresight problem. Also, fiscal policy is likely to be a response to the current state of economy even if the policy is unanticipated. The forecast error approach reduces the probability that the fiscal policy shock contains information about the current business cycle since most of the information about the business cycle in year $t$ would be contained in the forecast (published in October), not in the forecast errors.

8 The local projection method has been widely used in the literature of estimating fiscal multipliers (e.g., Auerbach and Gorodnichenko, 2013; Abiad et al., 2016; Ramey and Zubairy, 2018).

${ }^{9}$ It is important to keep in mind the caveat associated with the shock identification. As Jordà's (2005) local projection does not impose structure on the impulse response functions, this method is more robust to misspecification than standard VAR models, if the shocks are well-identified. However, the challenge to identify fiscal policy shocks in a satisfactory manner remains.

${ }^{10}$ We use the actual GDP as denominator for both actual and forecast series.
} 


\section{The output effect of fiscal policy is estimated using the following baseline specification:}

$$
y_{i, t+h}-y_{i, t-1}=\alpha_{i}^{h}+\gamma_{t}^{h}+\beta^{h} F E_{i, t}+\theta^{h} X_{i, t}+\varepsilon_{i, t}^{h}
$$

where $y_{i, t}$ is log of real GDP of country $i$ in year $t, \alpha$ is the country fixed effect, $\gamma$ is the time fixed effect, $F E$ is the identified fiscal policy shock, and $X$ is a set of control variables. We estimate the equation for each $h=0, \ldots, 3$, where $h=0$ is the year when the fiscal policy shock takes place. We compute the impulse response functions of variables of output by using the estimated $\beta^{h}$. The confidence intervals associated with the impulse response functions are obtained by the estimated (clustered robust) standard errors of the coefficient $\beta^{h}$.

18. We use annual data for 1995-2017 from the IMF's WEO database. Our analysis focuses on LICs as defined by the IMF. We further limit our sample by excluding resource rich countries (RR) and clean the data in the following manner. First, we limit the sample period to 1995-2017 because fiscal policy data for LICs before 1995 are scarce. We then construct the fiscal policy shocks using public investment and government consumption. Government spending shocks are calculated as the sum of these shocks. We drop the shock variables if the fiscal policy variable is an extreme outlier, the shock variable is exactly zero, or if the variable does not exist in the latest WEO publication. Lastly, the constructed shock variables and output variable are trimmed at 1 percent to remove outliers. We estimate the fiscal multipliers using the observations which have both government investment shock and government consumption shock variables to ensure that the sum of these two shocks define the government spending shocks. These restrictions result in 566 observations for 42 countries.

\section{RESULTS}

\section{Baseline Results}

19. Our baseline results confirm lower output effects of fiscal spending shocks in LICs, compared with AEs and EMs (Figure 2). By estimating equation (1), we examine the output effect of government spending shocks by income groups (AEs, EMs, and LICs). In all income groups, positive government spending shocks increase output. However, the size of the effect differs across income groups. In LICs, an unanticipated 1 percent of GDP increase in government spending increases output by 0.1 percent in the year of the shock and the output response becomes statistically insignificant after three years. The size of output responses to government spending shocks in LICs after three years is on average less than half of those in AEs and marginally smaller than those in EMs. ${ }^{11}, 12$ We find that the differences of the estimated output

\footnotetext{
${ }^{11}$ Estimated fiscal multipliers in AEs are somewhat lower than those in the literature. This may reflect differences in shock identification methods and specification of empirical models.

12 This is broadly consistent with the previous empirical studies finding larger fiscal multipliers in AEs than those in developing countries.
} 
effects are statistically significant between AEs and LICs in the medium term (years two and three after the shock), but not between EMs and LICs. ${ }^{13}$

Figure 2. Effects of Government Spending Shocks on Output

AEs

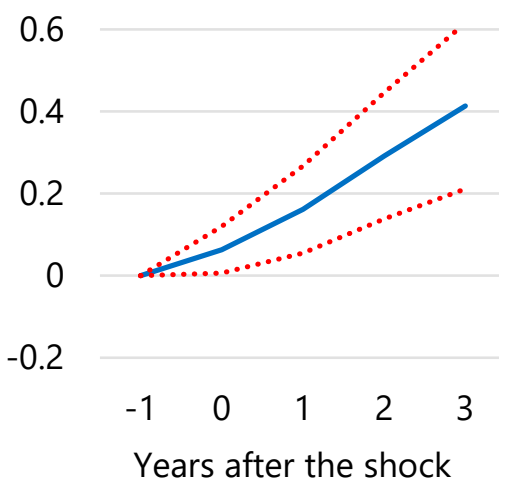

EMs

0.6

\section{4 \\ 0.2 \\ 0 \\ $-0.2$ \\ 0.4}
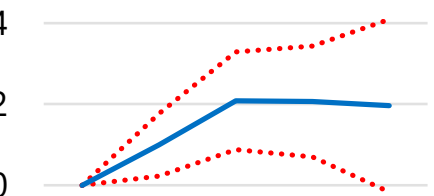

$-1$

Years after the shock

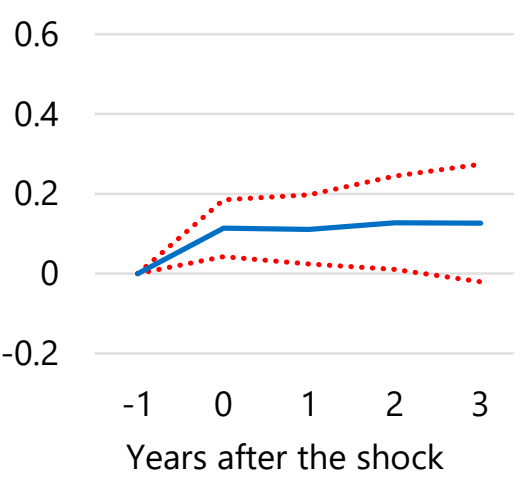

Note: $t=0$ is the year of the shock. Solid lines present the responses (in percent) to an unanticipated shock to government spending of 1 percentage point of GDP. Dashed lines denote 90 percent confidence bands. For AEs, the sample size is 507 (17 countries). For EMs, the sample size is 742 (55 countries). RR countries are excluded. The data for AEs comes from OECD Economic Outlook.

Source: Authors' calculations.

\section{Notably, the shape of the output effects differs significantly among the income}

groups. The output effects in EMs and LICs flatten a year after the shock, while in AEs, the effects continue to rise over three years. This likely reflects the secondary (or spillover) effects of the initial spending shocks to the private sector. In AEs where the private sector is developed, fiscal spending shocks stimulate private sector activities, however, this may not necessarily be the case in less developed countries. As a result, while the output effects in AEs are persistent, those in LICs are short-lived.

\section{Different behavioral responses by the private sector indeed appear to explain the} smaller output effects in LICs. To examine the role of private sectors, we further estimated the impact of spending shocks on private consumption and investment. The results (Annex I) show that while positive fiscal spending shocks foster private sector consumption and investment in

\footnotetext{
${ }^{13}$ It is important to note that an overlap of the confidence interval by itself does not imply that the differences are statistically insignificant. For example, Boeckx et al. (2019) show that the difference between the impulse responses are statistically significant though the confidence intervals overlap. To check whether the differences of output effects between LICs and AEs (EMs) are statistically significant, we nest the estimation for AEs and LICs within the single model and calculate the differences between output responses and the confidence bands of the differences. The differences are statistically significant at 5 percent level for AEs and LICs after $t=2$, while the differences for AEs and LICs are not statistically significant at any horizon.
} 
AEs, this is not the case in EMs and LICs. This difference in the private sector's behavioral responses likely contributes to the lower output effects of fiscal spending shocks in LICs.

22. Similar to the empirical results on AEs, our analysis also confirms different output effects of different fiscal policy instruments. Government spending shocks can be broken down into consumption and investment shocks. Figure 3 shows that public investment shocks have a larger effect than government consumption shocks, which is consistent with the literature (Ilzetzki et al., 2013). While output effects of public investment shocks are statistically significant over the horizon, the consumption shock increases output only when the shock takes place. The positive output effect of the consumption shock on impact contrasts with Ilzetzki et al., (2013) who find no statistically significant output effect of government consumption shocks in developing countries. In LICs, the output effect of public consumption shocks is relatively shortlived compared to AEs.

Figure 3. Output Effects of Different Fiscal Policy Shocks in LICs

\section{Fiscal Spending Shocks}

$$
0.4
$$

0.2

0

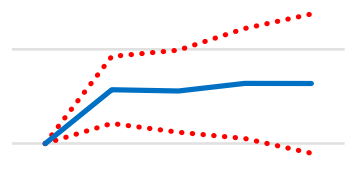

$-0.2$

\section{Government Consumption Shocks}

0.4

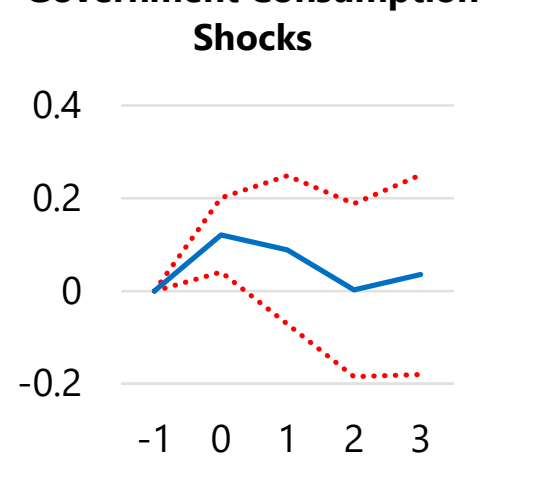

\section{0}

$-0.2$

\section{Capital Spending Shocks}

0.4

0.2

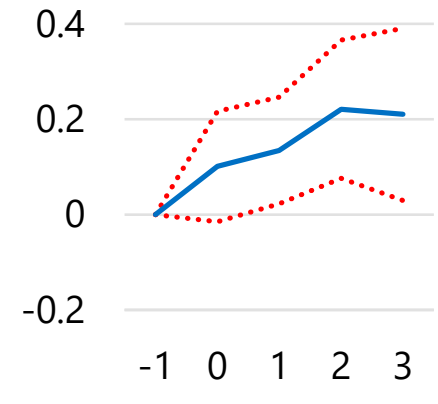

$-0.2$

Note: $t=0$ is the year of the shock. Solid lines present the responses (in percent) to an unanticipated shock to government spending of 1 percentage point of GDP. Dashed lines denote 90 percent confidence bands.

Source: Authors' calculations.

\section{These results have implications for a fiscal consolidation strategy. Cutting} government consumption—which may adversely affect growth at the outset-would not necessarily drag down growth over the medium term. If the government were to cut capital spending, however, adverse growth effects would build up over time, reflecting less productive capacity of the economy. Furthermore, the effects of fiscal stimulus centered on government consumption would only be temporary, leading to a waste of resources over time (if it is intended to stimulate growth).

\section{Extended Analysis}

24. Our analysis is further extended to examine the environments allowing larger or smaller output effects. Specifically, we examine all the determinants of the fiscal multiplier as discussed in IMF (2014). Those determinants are: 
- Business cycles,

- Trade openness,

- Exchange rate regimes,

- The level of public debt,

- Labor market rigidities,

- The size of automatic stabilizers,

- The quality of institutions.

25. To explore determinants of the size of the fiscal policy effect, we estimate the following non-linear model:

$$
y_{i, t+h}-y_{i, t-1}=\alpha_{i}^{h}+\gamma_{t}^{h}+\beta_{1}^{h} G\left(z_{i, t}\right) F E_{i, t}+\beta_{2}^{h}\left(1-G\left(z_{i, t}\right)\right) F E_{i, t}+\theta^{h} X_{i, t}+\varepsilon_{i, t}^{h}
$$

With

$$
G\left(z_{i, t}\right)=\frac{\exp \left(-\delta z_{i t}\right)}{1+\exp \left(-\delta z_{i t}\right)}, \delta>0
$$

where $G(\cdot)$ is the transition function and $z$ is an indicator of business cycle or country-specific characteristics, normalized to have zero mean and unit variance. As in Auerbach and Gorodnichenko $(2012 ; 2013)$ and IMF (2014), when $z$ takes the business cycle indicator, we set $\delta=1.5$, otherwise we set $\delta=1.0$. For the indicator $z$, we use real GDP growth as a measure of the business cycle, weighted average MFN tariff level as a measure of trade openness, the public debt-GDP ratio as the public debt level, an index averaging labor union power and collective disputes from Botero et al., (2004) as a measure of labor market rigidity, the ratio of government spending to GDP as a measure of automatic stabilizer, and government effectiveness indicators from the World Bank as the proxy of the quality of institutions. To examine the role of the exchange rate regimes, instead of using the smooth transition function, we estimate the equation with a dummy variable of fixed and floating exchange rate regimes. We use the classification provided by Ilzetzki et al., (2017) and divide observations into fixed exchange rate regimes and floating exchange rate regimes.

26. Among all the factors, our analysis finds that business cycles, exchange rate regimes, and the quality of institutions matter for the size of output effects of fiscal spending shocks.

\section{Business cycle:}

27. We first analyze the importance of the business cycle in determining the size of the output effects in LICs. Recent literature on fiscal multipliers finds that the impact of fiscal policy shocks depends crucially on the state of the business cycle (Auerbach and Gorodnichenko, 2012, 2013; Blanchard and Leigh, 2013; Dell'Erba et al., 2014; Ramey and Zubairy, 2018). To examine 
whether fiscal multipliers are state-dependent in LICs, we estimate equation (2) by using real GDP growth as a measure of the business cycle. ${ }^{14}$

\section{The results (Figure 4) point to highly state-dependent output effects in LICs, with}

larger effects during recessions than during booms. This result is broadly consistent with those for AEs (Auerbach and Gorodnichenko, 2012 and 2013). During booms, the output effects of positive spending shocks are negative but not statistically significant in most periods. During recessions, however, the output effects are positive, visible, and sizable, with statistically significant results over the estimation period, which is three years. The low output effects of fiscal spending shocks during booms likely reflect crowding out effects on private investment (Appendix II).

Figure 4. Output Effects of Fiscal Policy Shocks Over Business Cycles in LICs

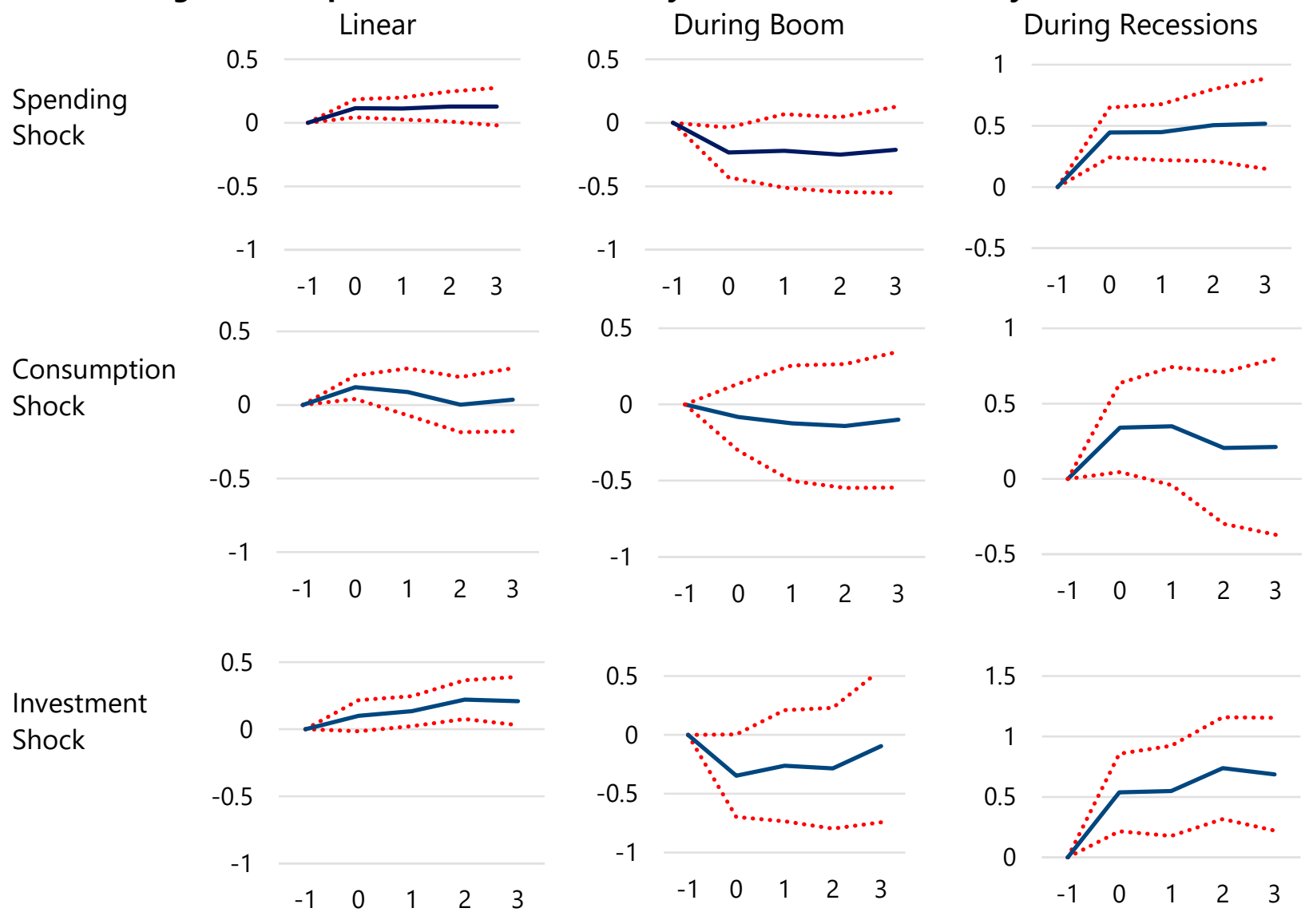

Note: $t=0$ is the year of the shock. Solid lines present the responses (in percent) to an unanticipated shock to government spending of 1 percentage point of GDP. Dashed lines denote 90 percent confidence bands.

Source: Authors' calculations.

\footnotetext{
14 Instead of using the output gap, we identify the state of the economy using GDP growth as the output gap is unobservable and subject to substantial and frequent revisions, and thus estimates of output gaps are typically surrounded by great uncertainty. However, as noted below, similar results are obtained when we use the estimated output gap as the business cycle indicator.
} 


\section{Further analysis confirms the state-dependent impact of government consumption} and capital spending shocks on growth. During booms, the shocks have no statistically significant impact on growth, suggesting that fiscal expansion, either through government consumption or capital spending, would not contribute to growth. During recessions, while both consumption and investment shocks have positive and statistically significant effects, the output effect of public consumption shocks is slightly lower and short-lived. The results again confirm the importance of properly designed adjustment policies. In case a country should face the immediate need of fiscal adjustment (e.g., owing to liquidity constraints) during recessions, cutting government consumption (rather than capital spending) would be less harmful for growth, particularly over the medium term.

\section{Exchange rate regimes:}

30. In LICs, the output effects of fiscal spending shocks tend to be larger under fixed exchange rate regimes (Figure 5). While positive government spending shocks increase output in economies with fixed exchange rate regimes, they do not significantly affect the output under flexible exchange rate regimes. ${ }^{15}$ This result is broadly consistent with the literature that finds smaller fiscal multipliers under floating exchange rate regimes in AEs and developing countries (Born et al., 2013; Ilzetzki et al., 2013). ${ }^{16}$ This result may be because exchange rate movements offset the impact of discretionary fiscal policy on the economy. A fiscal stimulus increases the interest rate (and possibly foreign capital inflows), imposing a pressure on domestic currency to appreciate. ${ }^{17}$ Under flexible exchange rate regimes, this pressure results in a decrease in exports and the initial impact of the fiscal stimulus would be offset.

\section{The results under floating regimes raise the question if spending shocks would} really have no positive impact on output under different circumstances. The analysis shown above confirms low and statistically nonsignificant effects of fiscal spending shocks. Given that this is estimated for the entire sample period, the question may still remain as to if robust output effects can be identified during recessions, such as in periods when larger output effects are generally estimated (Figure 4). Or, one may also ask if capital investment shocks (which are estimated to have larger output effects) can still have a positive impact. Thus, we further estimate the output effects of the shocks during recessions under floating regimes, and by different fiscal instrument shocks. The results (Annex III) reflect that fiscal spending shocks do not have a statistically significant output effect under floating exchange rate regimes, even when considering different states of the business cycle or different types of spending shocks (i.e., public investment shocks and government consumption shocks).

\footnotetext{
${ }^{15}$ We split the sample into economies with fixed and flexible exchange rate regimes as in Ilzetzki et al., (2011). That is, based on the de facto exchange rate arrangement classification of Ilzetzki et al., (2017), who define fixed exchange rate regimes as no separate legal tender, hard pegs, crawling pegs, or de facto/pre announced horizontal bands or crawling bands that are narrower than or equal $+/-2$ percent.

16 In contrast, as noted above, Kraay (2014) finds that fiscal multipliers are higher in countries with flexible exchange rate regimes.

${ }^{17}$ As the capital inflow is small in many LICs, this channel may be limited.
} 
Figure 5. Output Effects of Government Spending Shocks Under Different FX regimes in LICs

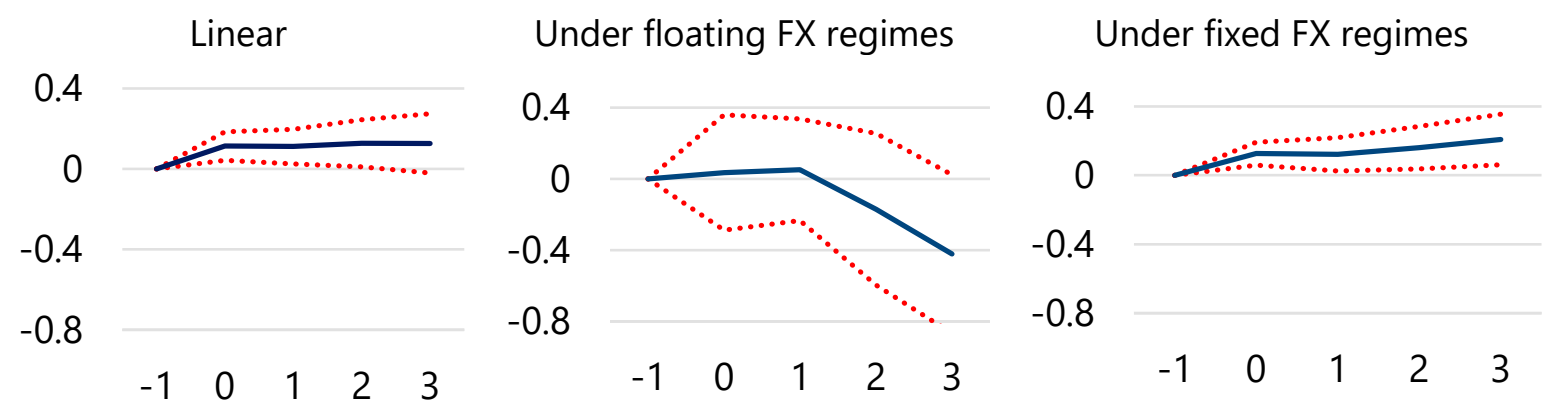

Note: $t=0$ is the year of the shock. Solid lines present the responses (in percent) to an unanticipated shock to government spending of 1 percentage point of GDP. Dashed lines denote 90 percent confidence bands. The definition of the exchange rate regime is based on Ilzetzki et al., (2017). We construct dummy variables that indicate a fixed or floating regime for a given year and country, as defined in Ilzetzki et al., (2013).

Source: Authors' calculations.

\section{Quality of institutions:}

32. The quality of institutions also plays an important role in determining the output effects of fiscal policy in LICs (Figure 6). Economies with higher institutional quality achieve a positive output impact of government spending shocks and it remains positive until two years after the shock. However, such an impact is not observed in economies with lower institutional quality. This result suggests that the effect of fiscal spending would be smaller when the quality of policy formulation and/or implementation is lower. In addition, we also use the Public Investment Management Index constructed by Dabla-Norris et al., (2012) as an alternative indicator and find that the results remain broadly the same.

Figure 6. Effects of Government Spending Shocks: The Role of the Institution Quality in LICs

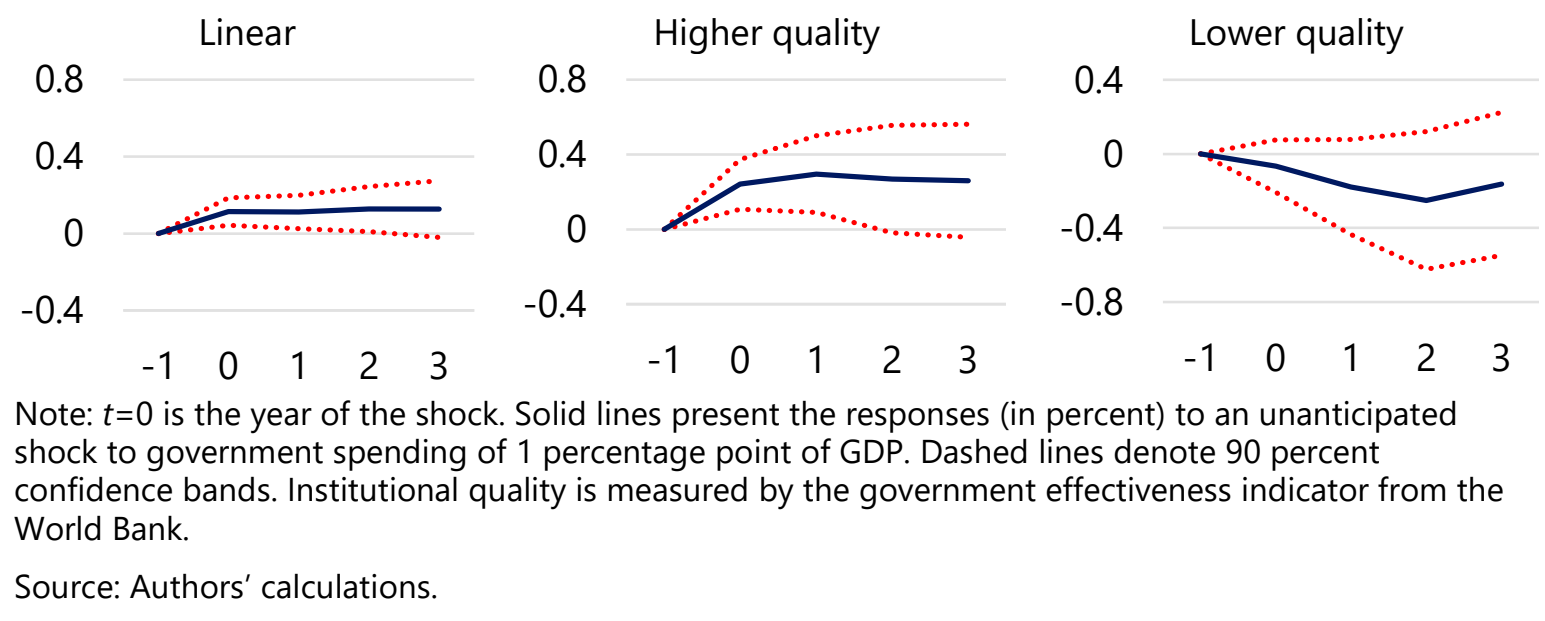




\section{Other Factors:}

33. Unlike the studies on AEs, our analysis could not identify the significant role of trade openness, the public debt level, the labor market rigidity, and the size of automatic stabilizer (Annex IV). Due to the underdeveloped market structure and/or noisy data in LICS, these determinants do not affect the size of fiscal multipliers in LICs. Also, there are possible differences in shock transmission mechanisms among those countries. Why do these determinants not affect the output effects in LICs?

- Trade openness. The effect of trade openness on fiscal multipliers is inconclusive. While the conventional wisdom points to more open economies tending to have smaller fiscal multipliers, recent studies show that fiscal multipliers in economies which are relatively open to trade are not necessarily smaller than their closed counterparts. ${ }^{18}$ Furthermore, if fiscal spending is inefficient (possibly owing to weak institutional quality), the initial rise in aggregate income would be small, which may not result in a rise in imports.

- Public debt level. If consumers face a binding liquidity constraint in LICs, fiscal stimulus would loosen the constraints, leading to immediate consumption increases. If this effect dominates the negative credibility and confidence effects of fiscal expansion on private demand, the high debt level may not imply lower output effects of fiscal spending shocks.

- Labor market rigidity. Limited data availability of the labor market rigidity measure for LICS may lead to insignificant findings. Moreover, our result may reflect the measurement error problem in LICs. Since the size of informal sectors in LICs is quite large, the quality of the measures regarding labor market rigidity could be lower compared to AEs. ${ }^{19}$

- The size of automatic stabilizers. A measurement problem may have led to the result of no impact. Due to data constraints, we use the ratio of public spending to nominal GDP as the measure of an automatic stabilizer, but this measure contains public spending other than those regarded as an automatic stabilizer. This inaccurate measurement may be one reason why we do not see clear relationship between the size of stabilizer and output effects. Another reason could be that the effectiveness or the size of stabilizer is smaller in developing countries than in AEs. ${ }^{20}$

\section{Dominance Analysis}

34. To examine which determinant plays the most important role among the three significant factors, we calculate the relative importance of each of them. For this purpose,

\footnotetext{
18 See Footnote 5 above for details.

${ }^{19}$ Botero et al., (2004) also mention that they would have a measurement error problem because some employment is informal, especially in developing countries.

20 IMF (2014) points out that the fiscal stabilizer is more effective in AEs than in EMs and LICs, reflecting the characteristics of these developing countries such as less potent fiscal instruments and lower priorities of stabilization.
} 
we employ the so-called dominance analysis (Budescu, 1993). We first estimate the following equation:

$$
y_{i, t+h}-y_{i, t-1}=\alpha_{i}^{h}+\gamma_{t}^{h}+\sum_{k \in K} \beta^{k} D_{i, t}^{k} F E_{i, t}+\varepsilon_{i, t}
$$

where $K$ is a set of significant determinants, that is, $K \in$ \{state of business cycle, exchange rate regime, institutional quality $\}. D_{i, t}^{k}$ is a dummy variable that takes 1 if determinant $k$ is above the threshold. ${ }^{21}$ Then we calculate what percentage of the variation in this model each explanatory variable explains in this specification as a proxy of relative importance of the determinants.

Figure 7. Relative Importance of Determinants (Percent)
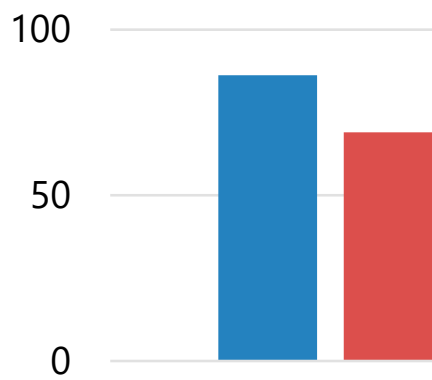

Business cycle

100

(Percent)

On impact

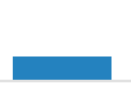

Exchange rate regime
Institution quality

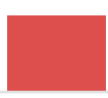

3 years after the shock

Note: The bars on the left represent the dominant statistics (relative importance) of each explanatory variable when the shock occurs, while the bars on the right represent those three year after the shock. We calculate the relative importance after excluding the variation explained by fixed effects.

Source: Authors' calculations.

35. We find that among these factors, the state of business cycle has the largest impact on the size of fiscal multipliers in LICs (Figure 7). On impact, the relative importance exceeds 80 percent, which is much larger than those of other two determinants. It remains so even three years after the shock while the relative importance of exchange rate regimes increases somewhat. These results imply that, while there are several important factors that determine the size of output effects, the relative importance of each factor could be quite different.

\section{This result implies that the output effects would be significantly lower in a country during economic booms, under floating exchange rate regimes, and with weaker institutions. Under such circumstances, fiscal consolidation can be undertaken with significantly lower impact on output. However, the adverse output effects would be larger-although still not overwhelming - in a country during recessions, under fixed exchange rate regimes, and with}

\footnotetext{
${ }^{21}$ The threshold is a median for the business cycle indicator and the institutional quality indicator. When $k=$ exchange rate regime, $D_{i, t}^{k}$ takes 1 with fixed exchange rate regimes under the classification employed in Ilzetski et al., (2013).
} 
better institutions. In particular, in view of the large impacts of the state of business cycle, the results confirm the importance of countercyclical fiscal policy.

\section{Box 1. Initial Capital Stock and Public Investment Shocks in LICs}

We also explored another factor for public investment, by analyzing whether an initial capital stock level affects the output effect of public investment shocks. Izquierdo et al., (forthcoming) find that, based on the sample of European countries, U.S. states and Argentine provinces, those with a lower level of initial capital stock have higher public investment multipliers. With the low level of an initial public capital stock, the marginal productivity of public investment would be high because there is more capacity and no crowd-out of private consumption or investment.

To examine whether this finding holds for LICs, we estimate the output effect of public investment shocks in LICs with higher and lower levels of initial capital stock. We use the average of the ratio of capital stock to GDP in $t-1$ to $t-3$ as a measure of initial capital stock and the nonlinear specification with the smooth transition function. The sample period is 1995-2017.

Our result-different from those in Izquierdo et al., (forthcoming)—suggests the existence of heterogeneity for LICs. Contrary to the findings of Izquierdo et al., (forthcoming) regarding AEs and EMs, for LICS, the output effects of public investment shocks are positive and significantly different from zero with the higher initial capital stock level, while the output effects are negative and insignificant with the lower initial capital stock level. For LICs, the private sector may not be responsive to fiscal policy shocks when the amount of initial capital stock is too low. Nevertheless, further investigation for the underlying mechanism is needed.

\section{Higher initial capital stock}

EMs

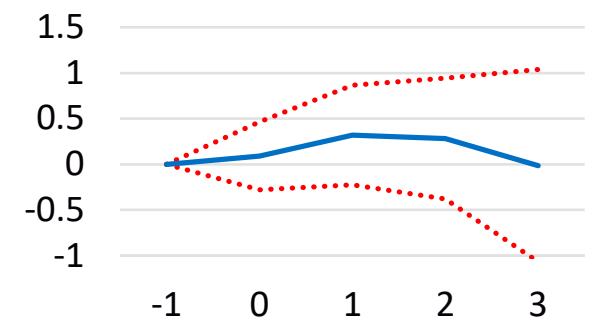

LICS

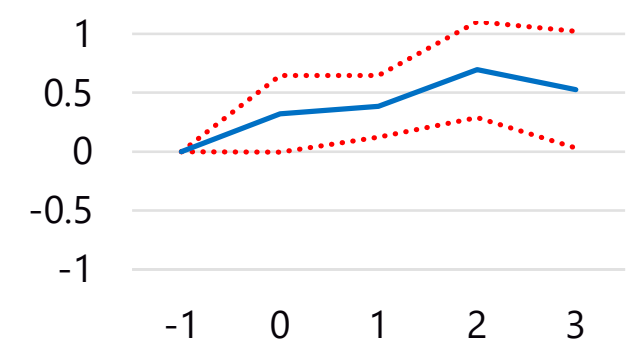

\section{Lower initial capital stock}
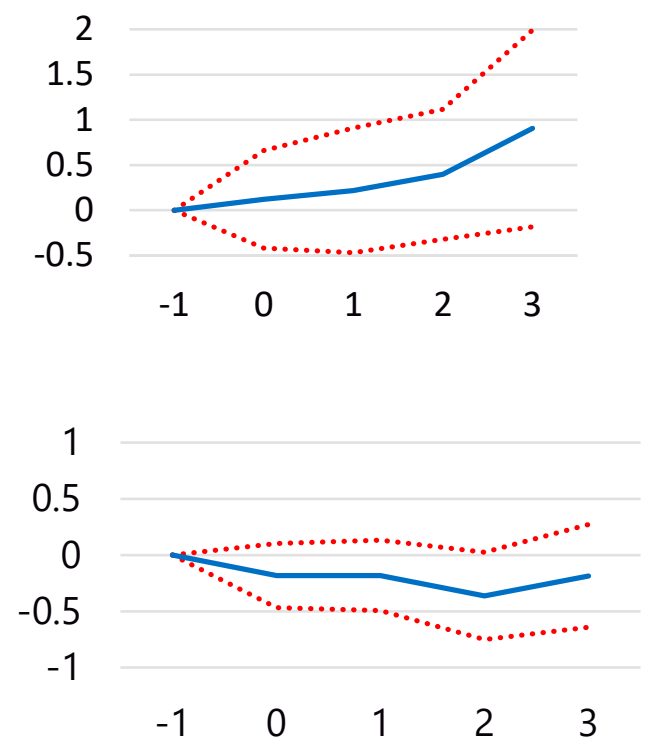

Source: Authors' calculations.

1 The capital stock comes from IMF-FAD (general government capital stock). As a robustness check, we use the average capital stock ratio to GDP in 1990-1994 and the result does not change. The results with physical capital stock index also deliver similar outcomes. 


\section{Robustness Checks}

37. These results are robust in several directions. Although the local projection method is more robust to misspecification (Jordà, 2005), we conduct several robustness checks: ${ }^{22}$

- Government spending shocks: We check whether our results hold for alternative measures of government spending shocks. Instead of using the forecasts made in October of the same year, we use the forecasts from October of the previous year and April of the same year to compute the forecast errors of government spending. Our results remain broadly unchanged with the alternative shock series. We also add current and lagged output growth innovations as control to address endogeneity concerns and confirm that our main results are robust. Furthermore, we examined whether the sign of government spending shocks matter. By introducing a dummy variable that takes value one for positive shocks and zero otherwise, we find that there are no statistically significant differences between positive and negative shocks.

- Control variables: We also consider different combinations of control variables and lag length (e.g., public sector debt, inflation, fiscal variables, revenue shocks, and monetary policy measure). Our main results broadly remain unchanged with the regressions using these variables.

- Sample periods: To assess the robustness of our results to the sample, we estimate the model with different sample periods. Instead of using the data from 1995, we use the longest available sample period for each country and find that the results are broadly the same.

- Business cycles: We test a different measure of slack using output gap instead of the growth rate. The main results remain unchanged.

\section{CONCLUSION AND Policy IMPLICATIONS}

38. This paper finds that the output effects of government spending shocks in LICs are notably smaller than those in AEs and slightly smaller than those in EMs. On average, the fiscal multipliers in LICs are less than half of those in AEs. We also confirm that different fiscal policy instruments have different output effects, similar to the empirical results on AEs. Specifically, while the effects of government consumption shocks are temporary, public investment shocks have a larger and long-lasting effect.

39. We also find that in LICs as in AEs and EMs, the size of the output effects of fiscal policy shocks is larger (i) during recessions; (ii) under fixed change rate regimes; and/or (iii) with higher institution quality. Regarding exchange rate regimes, under floating exchange rate regimes, positive output effects are not found even during recessions. Among those three

\footnotetext{
22 The results of these robustness checks are available upon request.
} 
factors, we find that the state of the economy is most important in determining the size of the output effects.

40. Important policy implications can be drawn from our findings. First, in estimating the output effects in LICs, the state of the economy and the country's structural characteristics, such as exchange rate regimes and quality of institutions, should be considered, preferably with different weights. Second, as the output effects of fiscal spending are low in LICs, the output costs of fiscal adjustment appear not very high. Third, in view of state dependent output effects, our results suggest that undertaking countercyclical fiscal policy is essential. Moreover, under floating exchange rate regimes, the output effects of fiscal spending appear non-existent. Lastly, our results also suggest that LICs should enhance institutional quality to promote growth stimulus of fiscal spending.

41. Our results imply that the output costs of fiscal adjustment in LICs may not be as large as previously thought, especially if adopted outside of a recession, under a floating exchange rate regime, based on cutting public consumption, and/or accompanied by reform to enhance institutions. 


\section{REFERENCES}

Abiad, A., D. Furceri., Topalova, P., 2016. "The Macroeconomic Effects of Public Investment: Evidence from Advanced Economies." Journal of Macroeconomics, 50: pp. 224-240.

Auerbach, A., Gorodnichenko, Y., (2012), "Measuring the Output Responses to Fiscal Policy," American Economic Journal: Economic Policy 4(2): pp. 1-27.

Auerbach, A., Gorodnichenko, Y., (2013), "Fiscal Multipliers in Recession and Expansion," In Fiscal Policy After the Financial Crisis, edited by Alberto Alesian and Francesco Giavazzi, pp. 63-98. University of Chicago Press.

Barrell, R., D. Holland, and I. Hurst, 2012, "Fiscal Consolidation: Part 2. Fiscal Multipliers and Fiscal Consolidations," OECD Economics Department Working Paper No. 933 (Paris:

Organisation for Economic Co-operation and Development).

Blanchard, O. and R. Perotti, "An empirical characterization of the dynamic effects of changes in government spending and taxes on output," the Quarterly Journal of economics 117 (2002), pp. 1329-1368.

Blanchard, O., and D. Leigh, 2013, "Growth Forecast Errors and Fiscal Multipliers," American Economic Review, Vol. 103, No. 3, pp. 117-20.

Boeckx, J, M. Dossche, A. Galesi, B. Hofmann, G. Peersman, 2019, "Do SVAR with sign restrictions not identify unconventional monetary policy shocks?," BIS Working Papers No 788.

Born, B. F. Juessen, G.J. Mueller, 2013, "Exchange Rate Regimes and Fiscal Multipliers," Journal of Economic Dynamics and Control, Vol. 37, No. 2, pp. 446-65.

Budescu, D.V. (1993) Dominance Analysis: A New Approach to the Problem of Relative Importance of Predictors in Multiple Regression. Psychological Bulletin, 114, 542-551.

Cacciatore, M., and N. Traum, 2019. "Trade Flows and Fiscal Multipliers." Mimeo.

Cole, H.L., and L.E. Ohanian, 2004, "New Deal Policies and the Persistence of the Great Depression: A General Equilibrium Analysis," Journal of Political Economy, Vol. 112, No. 4, pp. 779-816.

Dabla-Norris, E., Brumby, J., Kyobe, A., Mills, Z., and Chris Papageorgiou, 2011, "Investing in Public Investment: An Index of Public Investment Efficiency," IMF Working Paper 11/37.

Dolls, M., C. Fuest, and A. Peichl, 2012. "Automatic Stabilizers and Economic Crisis: US vs. Europe," Journal of Public Economics, Vol. 96, pp. 279-94.

Furceri, D., B. Li, 2017, "The Macroeconomic (and Distributional) Effects of Public Investment in Developing Economies." International Monetary Fund Working Paper, No. 17-217. 
IMF, 2014, "Public Expenditure Reform: Making Difficult Choices," Fiscal Monitor, April.

IMF, 2014, "Fiscal Multipliers: Size, Determinants, and Use in Macroeconomic Projections," Technical Notes and Manuals 14/04 .

IMF, 2018, "Macroeconomic Developments and Prospects in Low-Income Developing Countries-2018", IMF Policy Paper.

Ilzetzki E., E. G. Mendoza, and C. A. Vegh, 2013, "How Big (Small?) Are Fiscal Multipliers?" Journal of Monetary Economics, Vol. 60, pp. 239-54.

Ilzetzki, E., C. M. Reinhart, and K. S. Rogoff, 2017, "Exchange Arrangements Entering the 21st Century: Which Anchor Will Hold?" NBER Working Paper No. 23134.

Izquierdo, A., R. Lama, J. P. Medina, J. Puig, D. Riera-Crichton, C. Vegh, and G. Vuletin, "Is the Public Investment Multiplier Higher in Developing Countries? An Empirical Exploration," IMF Working Paper (forthcoming).

Jordà, Ò., (2005), "Estimation and Inference of Impulse Responses by Local Projections," American Economic Review 95(1): pp. 161-182.

Kirchner, M., J. Cimadomo, and S. Hauptmeier, 2010, "Transmission Of Government Spending Shocks In The Euro Area: Time Variation and Driving Forces," ECB Working Paper Series 1219 (Frankfurt: European Central Bank).

Koh, W.C., (2017), "Fiscal multipliers: new evidence from a large panel of countries," Oxford Economic Papers, Vol. 69 (3), pp. 569-590,

Kraay, A. (2012). How large is the government spending multiplier? Evidence from World Bank lending. The Quarterly Journal of Economics, 127(2), pp. 829-887.

Kraay, A. (2014). Government spending multipliers in developing countries: evidence from lending by official creditors. American Economic Journal: Macroeconomics, 6(4), pp. 170208.

Leeper, E.M., Richter, A.W., Walker, T.B., 2012. Quantitative effects of fiscal foresight. American Economic Journal: Economic Policy, 4 (2), pp. 115-144.

Leeper, E.M., Walker, T.B., Yang, S.-C.S., 2013. Fiscal foresight and information flows. Econometrica 81 (3), pp. 1115-1145.

Miyamoto, Wataru, Thuy Lan Nguyen, and Viacheslav Sheremirov. "The effects of government spending on real exchange rates: Evidence from military spending panel data." Journal of International Economics 116 (2019): pp. 144-157. 
Ramey, V. A. (2011): "Can Government Purchases Stimulate the Economy?" Journal of Economic Literature, 49, pp. 673-685.

Ramey, V. A. and M. D. Shapiro, "Costly capital reallocation and the effects of government spending," in Carnegie-Rochester Conference Series on Public Policy, Vol. 48 (Elsevier, 1998), pp. 145-194.

Ramey, V.A., Zubairy, V. (2018), "Government Spending Multipliers in Good Times and in Bad: Evidence from U.S. Historical Data," Journal of Political Economy, 126:2, pp. 850-901. 


\section{Annex I. Impacts of Fiscal Spending Shocks on Private Consumption and Investment}

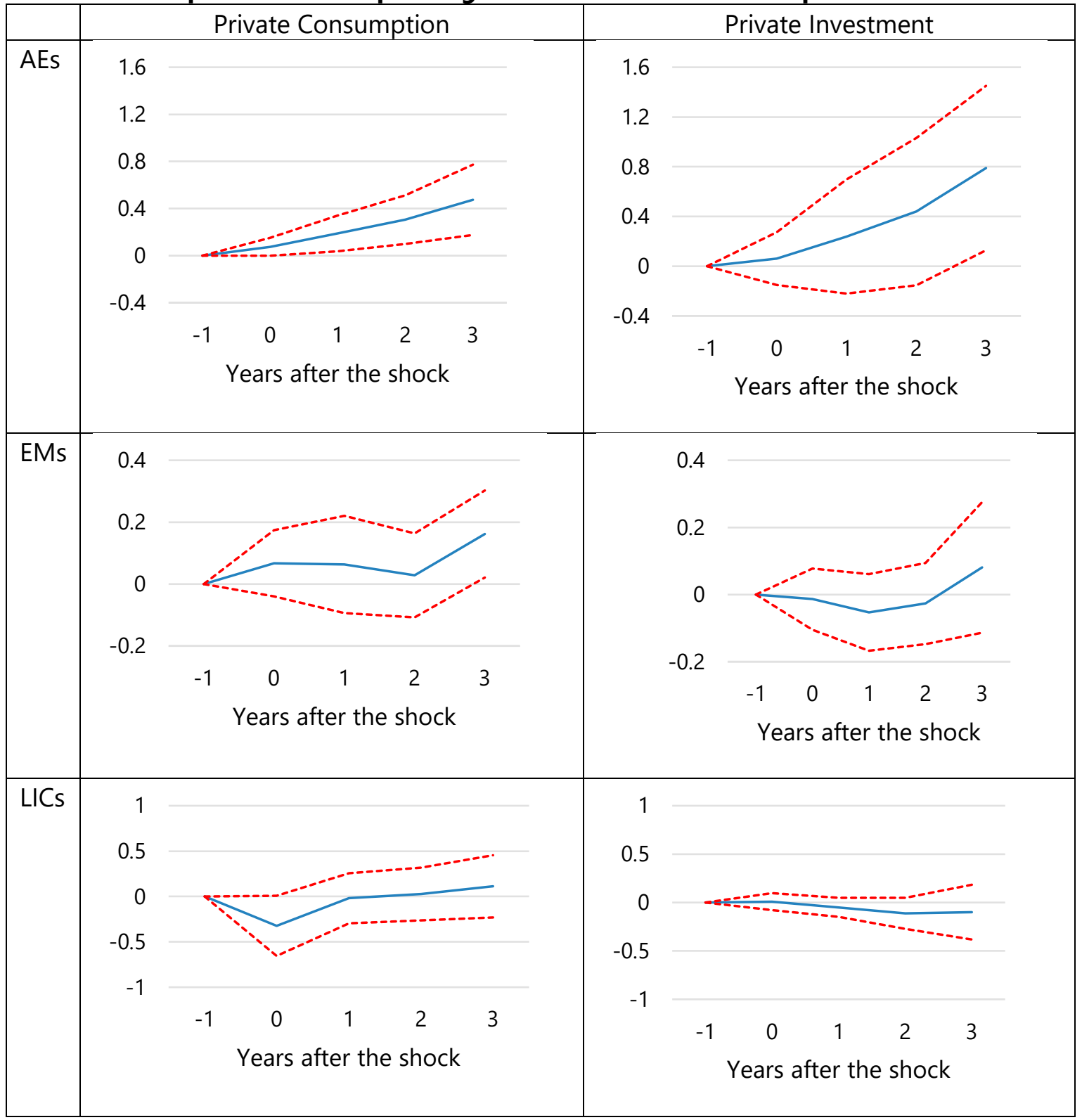

Note: $\mathrm{t}=0$ is the year of the shock. Solid lines present the responses (in percent) to an unanticipated shock to government spending of 1 percentage point of GDP. Dashed lines denote 90 percent confidence bands. Source: Authors' calculations. 
Annex II. Impacts of Fiscal Spending Shocks on Private Consumption and Investment in LICs During Booms

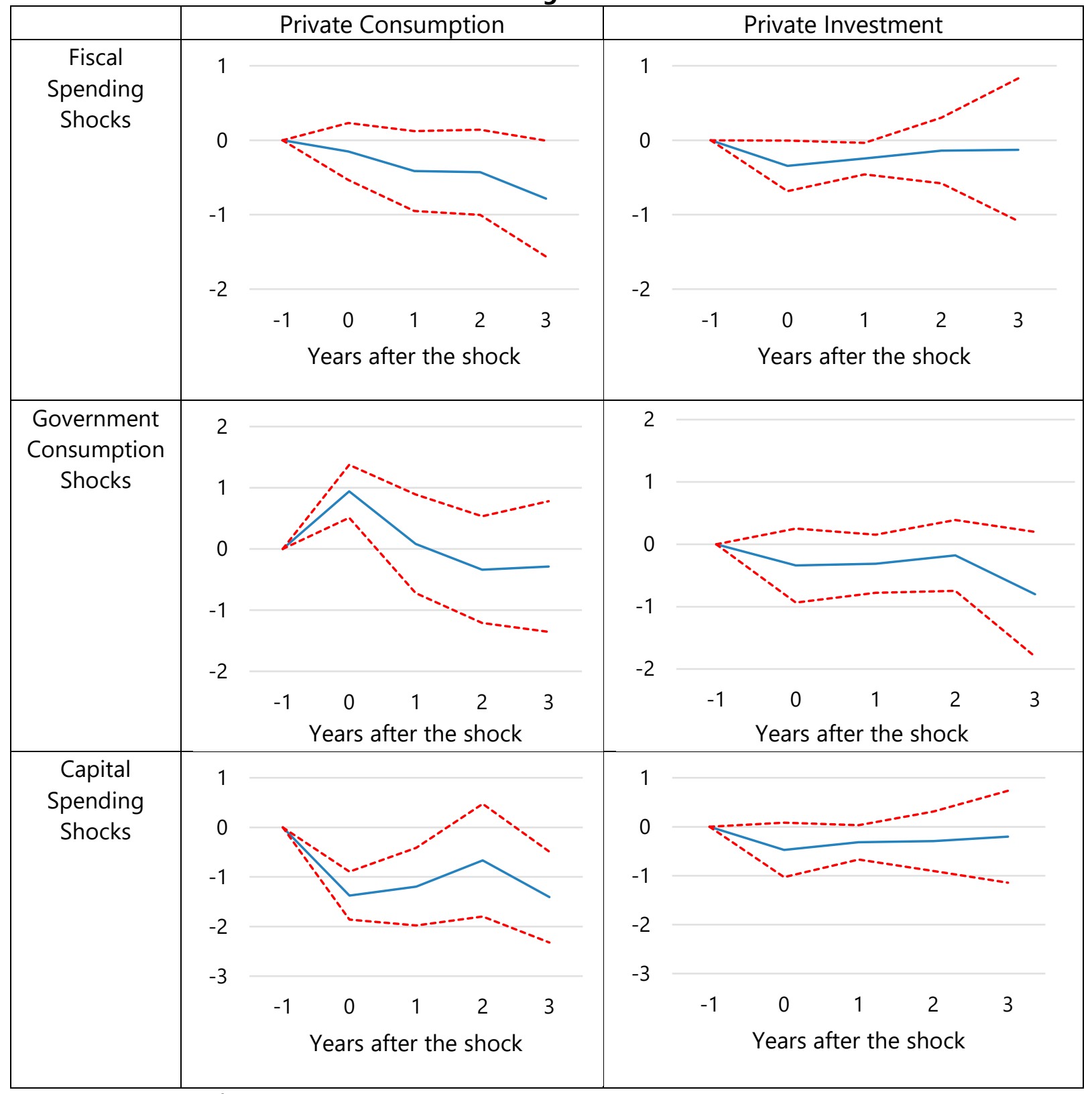

Note: $t=0$ is the year of the shock. Solid lines present the responses (in percent) to an unanticipated shock to government spending of 1 percentage point of GDP. Dashed lines denote 90 percent confidence bands.

Source: Authors' calculations. 
Annex III. Output Effects of Fiscal Spending Shocks Under Floating Exchange Rate Regimes in LICs

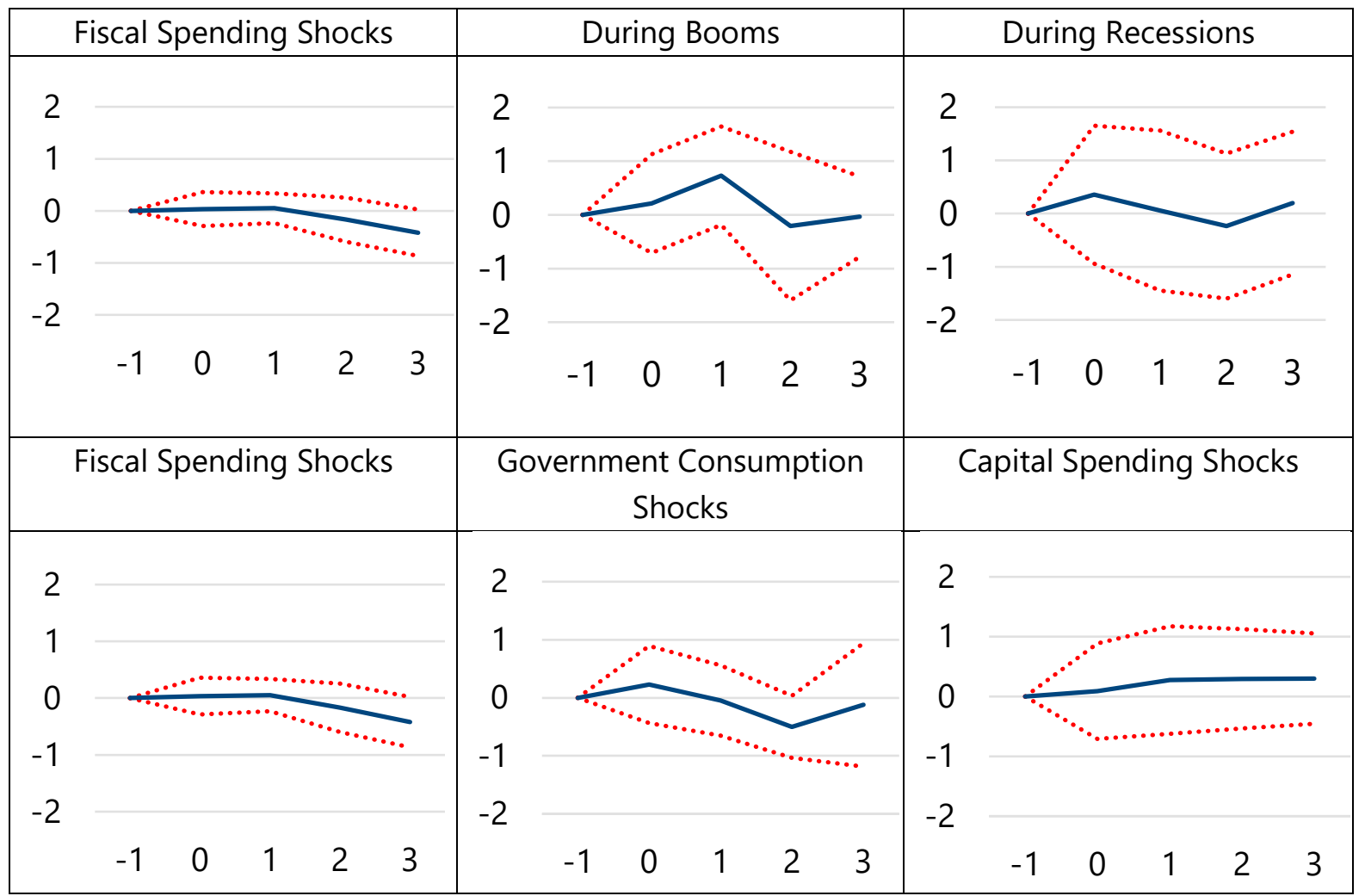

Source: Authors' calculations. 
Annex IV. Possible Determinants of the Size of Fiscal Multiplier

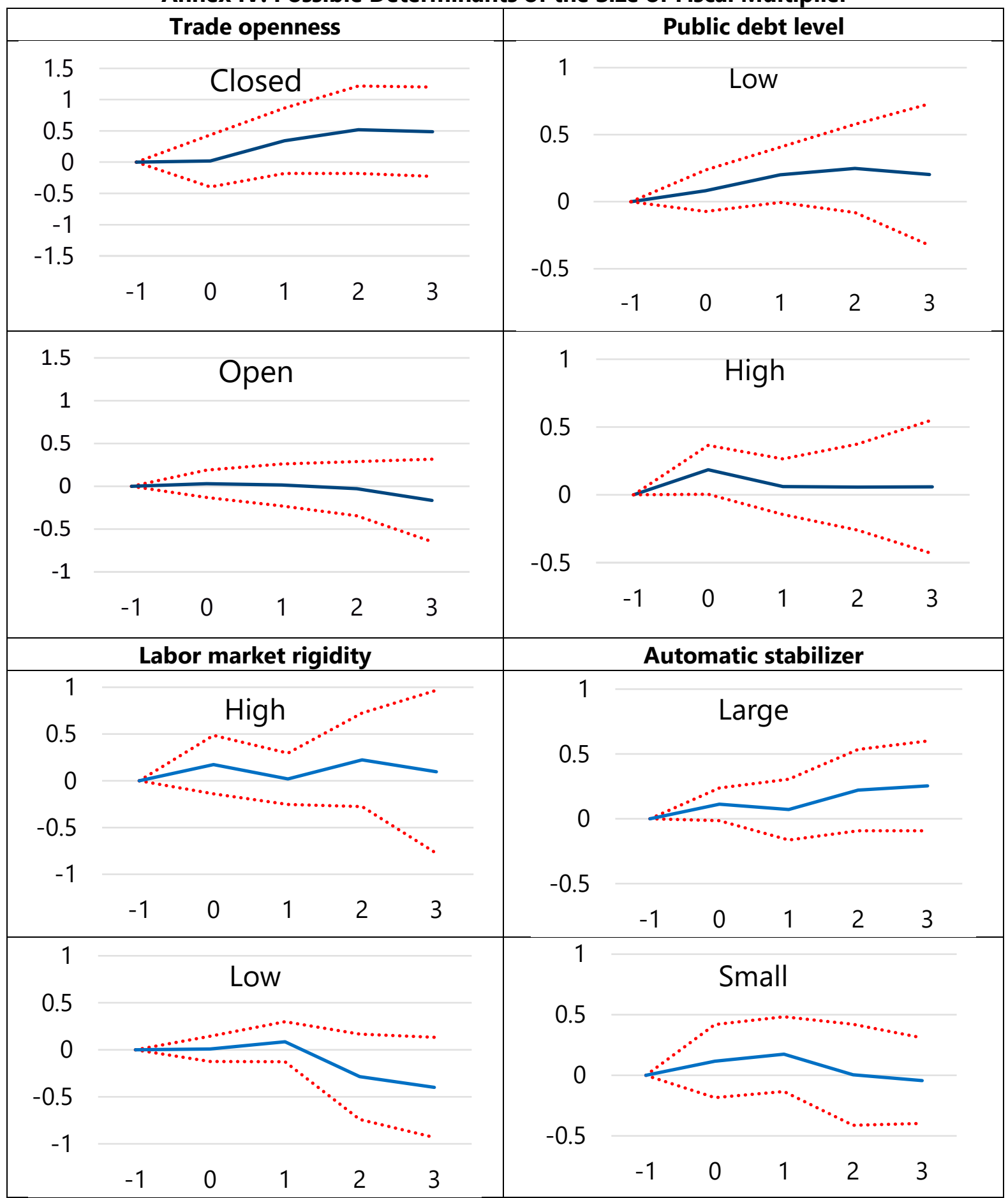

Note: $t=0$ is the year of the shock. Solid lines present the responses (in percent) to an unanticipated shock to government spending of 1 percentage point of GDP. Dashed lines denote 90 percent confidence bands.

Source: Authors' calculations. 